
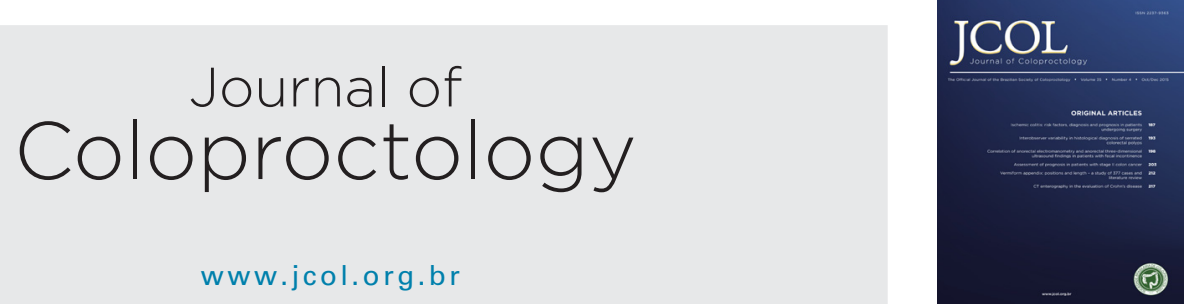

Review Article

\title{
Anatomical, surgical and clinical considerations related with operative procedures performed in combined abdominal and perineal approaches for the treatment of lower rectal cancer
}

\author{
Ali Naki Yücesoy \\ Batı Bahat Hospital, General Surgery Department, Istanbul, Turkey
}

\section{A R T I C L E I N F O}

Article history:

Received 13 June 2017

Accepted 18 September 2017

Keywords:

Lower rectal cancer

Combined abdominal and perineal

approach

Sphincter-saving surgery

\begin{abstract}
A B S T R A C T
Background and aim: Combined abdominal and perineal (anterior or posterior) approaches used in lower rectal cancer surgery have been based on similar anatomical and surgical features. The main aim of this manuscript is to evaluate the results of combined approaches performed for lower rectal cancer and to comment on surgical and anatomical features of the operations.

Methods: Anatomical, surgical and clinical details of the combined abdominal and perineal approaches performed for lower rectal cancer were evaluated by reviewing published articles about this subject in English in PubMed, EMBASE, Cochrane library and other sources.

Results: Ten articles including case reports were found on combined abdominal and perineal approaches published between 2003 and 2015. There were 83 patients who had been operated by using combined approaches for lower rectal cancer surgical treatment in these series. While the circular resection margine positivity had not been reported in the cases; the mean Wexner continence score had been reported between 5 and 5.5. The most important dissatisfaction of these surgical methods has been reported as persistent perineal fistulas encountered $9.6 \%$ of the patients in average in the postoperative period.

Conclusion: The APPEAR (Anterior Perineal Plane for Ultra Low Anterior Resection) procedure is the most known surgical procedure in which the combined abdominal and anterior perineal approach is used. Combined abdominal and perineal (anterior or posterior) approaches can be described as surgical procedures in which the sphincter-saving extrasphincteric dissection and proximal segmental sphincteric excision techniques are performed.

(c) 2017 Sociedade Brasileira de Coloproctologia. Published by Elsevier Editora Ltda. This is an open access article under the CC BY-NC-ND license (http://creativecommons.org/
\end{abstract} licenses/by-nc-nd/4.0/). 


\section{Considerações anatômicas, cirúrgicas e clínicas relacionadas a procedimentos operatórios realizados em abordagens abdominais e perineais combinadas para o tratamento de câncer retal baixo}

\author{
R E S U M O
}

Experiência e objetivo: As abordagens abdominais e perineais (anterior ou posterior) combinadas, utilizadas na cirurgia para o câncer retal baixo, têm se baseado em características anatômicas e cirúrgicas similares. O objetivo principal desse estudo é avaliar os resultados de abordagens combinadas realizadas em pacientes com câncer retal baixo e também comentar as características cirúrgicas e anatômicas das operações.

Métodos: Avaliamos os detalhes anatômicos, cirúrgicos e clínicos das abordagens abdominais e perineais combinadas para o câncer retal baixo por meio de uma revisão dos artigos publicados no idioma inglês sobre esse tópico em PubMed, EMBASE, Cochrane Library e outras fontes.

Resultados: Encontramos 10 artigos, inclusive relatos de casos, sobre abordagens abdominais e perineais combinadas publicados entre 2003 e 2015. Nessas séries, 83 pacientes no total tinham sido operados com o uso de abordagens combinadas para o tratamento de câncer retal baixo. Embora a positividade para ressecção circular da margem não tenha sido informada nos casos, foi relatado um escore de Wexner para continência que variou de 5-5,5. A insatisfação mais importante relatada com esses métodos cirúrgicos foi a persistência de fístulas perineais, em uma média de $9,6 \%$ dos pacientes no período pós-operatório.

Conclusão: APPEAR é o procedimento cirúrgico mais conhecido; com seu uso, emprega-se a abordagem abdominal/perineal anterior combinada. As abordagens abdominais e perineais (anterior ou posterior) combinadas podem ser descritas como procedimentos cirúrgicos nos quais são realizadas técnicas de dissecção extra-esfinctérica (com preservação do esfíncter) e de excisão esfinctérica segmentar proximal.

○ 2017 Sociedade Brasileira de Coloproctologia. Publicado por Elsevier Editora Ltda. Este é um artigo Open Access sob uma licença CC BY-NC-ND (http://creativecommons.org/ licenses/by-nc-nd/4.0/).

\section{Introduction}

The rectum has limited surgical access as depending to its anatomical features which is embedded into its visceral neighbors and pelvic musculature. Classically, the rectum is $17-18 \mathrm{~cm}$ in length. It can be examined surgically as three parts; upper, middle and lower thirds, each one is roughly $6 \mathrm{~cm}$ in length. Anatomically, the rectum can be investigated as two parts (supralevator part and sublevator part) by considering the levator ani muscle. The sublevator part of the rectum forms the surgical anal canal together with external anal sphincteric musculature embedded into lipomatous tissue in ischioanal fossa which surounds it. The surgical anal canal resembles two intertwined cylindrical muscular tubes. External sphincteric musculature constitutes the outer one of the intertwined two muscular tubes. External anal sphincteric system has a coil-like shape formed mainly by a narrow muscular tube. Inner muscular tube situated into coil-like external sphincteric system is formed by anatomical anal canal and distal part of the lower rectum.

Intersphincteric space is a potential space between the two cylindrical muscular tube in which intersphincteric dissection is carried out. While the internal anal sphincteric system, which is derived from endoderm and innervated by autonomous nervous system, and formed by thickening of the internal circuler muscle, can be considered as a part of the bowel wall; the external anal sphincteric system which is derived from ectoderm and innervated by somatic nervous system cannot be considered as a part of the bowel wall. While the internal anal sphincteric muscle provides the unconscious continence measured by resting anal pressure, the external anal sphincteric musculature provides the conscious continence measured by squeezing anal pressure. Anus is closed by the external and internal sphincteric systems which provide its air-tight characteristic. It should be kept in mind that anorectal area is one of the embryonic transition zones between endoderm and ectoderm. All of the anatomic and physiologic features (e.g. the transition from cubical epithelium to squamous epithelium, from autonomous innervation to somatic innervation, from smooth muscle to striated muscle, from unconscious movement to conscious movement) of the embryonic endo-ectodermal transition zones can be observed in the anorectal area.

Rectal cancer, especially lower rectal cancer, is a challenging problem for surgeons. Sphincter-saving surgery has become one of the gold standards in rectal cancer surgery after the total mesorectal excision procedure, which was described by Heald in $1982 .{ }^{1}$ In spite of the surgical improvements, the lower rectal cancer surgery has remained as a surgical challenge depending to its higher anal sphincter compromising, permanent colostomy and locoregional recurrence ratios compared to other parts of the rectum. Anatomical features of the lower rectum constitutes one of the most important causes 
of the surgical failures encountered in lower rectal cancer surgery. There is no doubt that a clear surgical access may not be achieved on the lower parts of the rectum only by the abdominal way. It is seems that difficult surgical access of the rectum has forced the surgeons for many years to find different ways for clear surgical access to the rectum. It has been observed that transvaginal, transperineal, transsacral or transanal routes have been used in rectal cancer surgery in addition to abdominal access. ${ }^{2-5}$ In spite of all these efforts, the lower rectal cancer has remained as a surgical trouble for surgeons. Current sphincter-saving surgical techniques in lower rectal cancer surgery have been built on the basis of the intersphincteric dissection technique described by Schiessel et al. ${ }^{6}$

Recent improvements related with anatomical knowledge and surgical techniques have brought new horizons to the sphincter-saving surgical treatment of the rectal cancer. One of the new surgical techniques is the combined abdominal and perineal approaches. The APPEAR procedure is the most popular one performed in the anterior perineal plane. ${ }^{7}$

Actually, all of the combined abdominal and perineal (anterior or posterior) rectal resection techniques have similar surgical and anatomic features. Combined abdominal and perineal surgical approaches have been structured on the basis of the anatomical and surgical features that are different from the intersphincteric dissection technique. The main reason of anatomical and surgical differences in combined approaches is the perineal access use. The main aim of the perineal access in combined approaches is to provide extrasphincteric rectal exposition on surgical anal canal localized in the ischiorectal fossa. Extrasphincteric dissection on the surgical anal canal provided by the perineal approach reveals the anatomical and surgical features of the combined abdominal and perineal approaches which are different from the intersphincteric dissection techniques.

\section{Materials and methods}

\section{Search strategy}

Anatomical, surgical and clinical considerations related with operative procedures performed during combined abdominal and perineal approaches for surgical treatment of lower rectal cancer were done by systematically reviewing the literature by using the following medical subject keywords for published studies between 2003 and 2015 in English in PubMed, EMBASE, Cochrane Library and other sources: "lower rectal cancer", "APPEAR procedure", "combined abdominal and perineal approach", "transvaginal”, "transperineal”. Case reports and series performed by using the combined abdominal and perineal approaches for lower rectal cancer have been taken into account for the evaluation.

\section{Surgical details of the combined abdominal and perineal approaches}

Combined abdominal and perineal approaches are carried out as two phases including abdominal and perineal phase in the patients, who have lower rectal cancer in Lloyd-Davies lithotomy position. Open or laparoscopic surgery can be used for the abdominal phase of the operation. Abdominal phase, which can be defined as supralevator part of the operation, includes the rectosigmoid dissection and total mesorectal excision until it reaches to levator ani muscle level. Perineal phase can be defined as sublevator part of the operation. While the supralevator abdominal phase is very familiar for surgeons, the sublevator perineal phase may not be familiar for most of them. Anterior perineal access can be provided by performing anterior transverse or vertical perineal incisions. We prefer the vertical perineal incision for avoiding of pudendal nerve terminal branches injuries in male patients. Also, transvaginal access provides a perfect sublevator level surgical access in female patients. Perineal access (anterior or posterior) use provides extrasphincteric dissection possibility on surgical anal canal in sublevator level in the ischioanal fossa (Fig. 1A and B). When the extrasphincteric dissection is completed by using transperineal or transvaginal ways, external sphincteric musculature resembling a coil is encountered. It should be remembered that external sphincteric musculature and distal part of lower rectum are arranged as intertwined two muscular tubes in the ischioanal fossa. When the perineal extrasphincteric dissection line reach up to puborectal muscle level, the fibrous adhesions between the deep external anal sphincteric muscle and the puborectal muscle must be separated. By doing so, full rectal mobilization is achieved by connecting the abdominopelvic and ischioanal spaces with each other at puborectal muscle level. The distal resection line was determined and the fixation sutures were placed by using transperineal access. When the distal rectal resection is performed in extrasphincteric plane in sublevator level, the distal rectal resection line is in the transsphincteric plane (Fig. 2A and $\mathrm{B}$ ). In this way, the proximal segment of the external sphincteric musculature in between the puborectal muscle level and distal rectal resection line is resected together with the corresponding distal rectal segment. The distal anal external sphincteric segment was fixated to bowel edges to prevent sphincteric retraction, after the transsphincteric distal rectum resection was performed. Internal anal sphincteric muscle is generally protected or its proximal part can be resected as dependent to distal rectal resection level. A full-thickness colo-anal anastomosis is performed between the colon and the remained distal anal segment by using perineal access (Fig. 3A and B). Ischioanal fossa does not contain mesorectal tissue.

Therefore, total mesorectal excision is carried out in the abdominal phase of the operation. The main surgical details of the combined abdominal and perineal approaches are illustrated in Fig. 4.

The following anatomical differences are remarkable when the perineal phases of the operation are compared between males and females. Surgical anal canal length in females is shorter than in males. The external anal sphincteric musculature in males is constituted by thicker muscles than in females. In men, there are more tight fibrous adhesions between of puborectal muscle and deep external anal sphincter muscle than in women. So, the full rectal mobilization procedure connecting supralevator abdominopelvic and sublevator ischioanal compartments is performed easily in females than in males. 

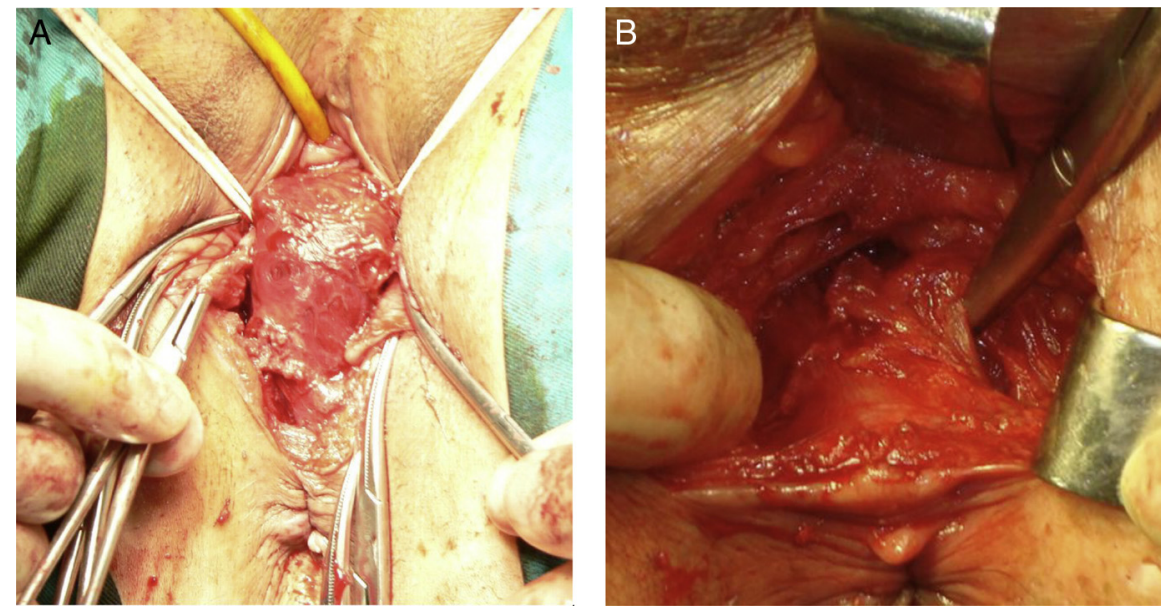

Fig. 1 - A, sublevator extrasphincteric rectal dissection by using transvaginal anterior perineal approach in a female patient; B, sublevator extrasphincteric rectal dissection by using anterior transperineal approach in a male patient.
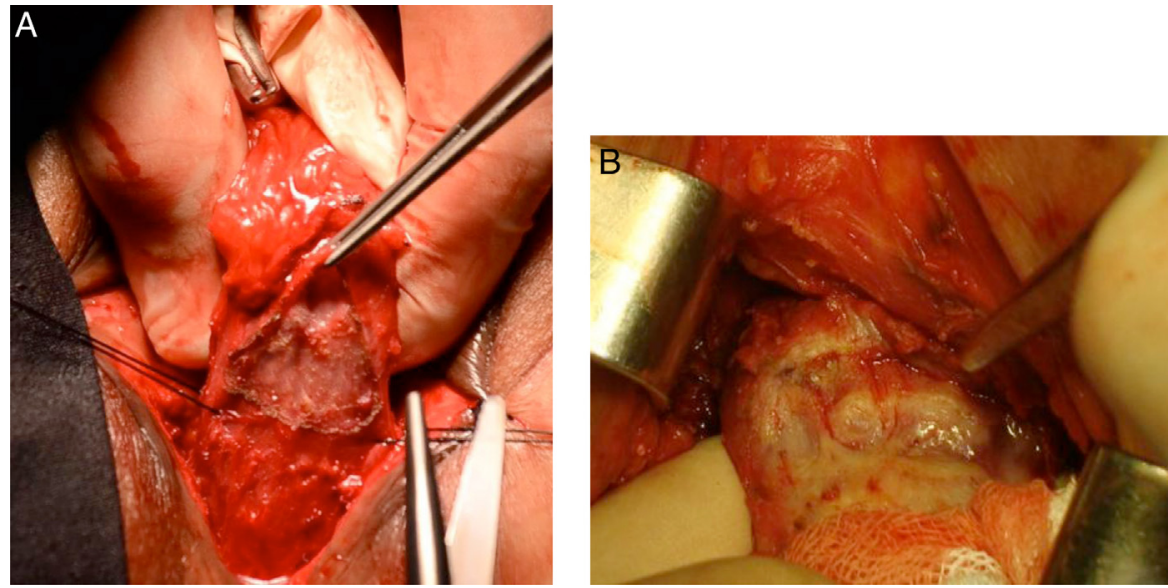

Fig. 2 - A, sublevator trans-sphincteric rectal resection by using transvaginal anterior perineal approach in a female patient; B, sublevator trans-sphincteric rectal resection by using anterior transperineal approach in a male patient.
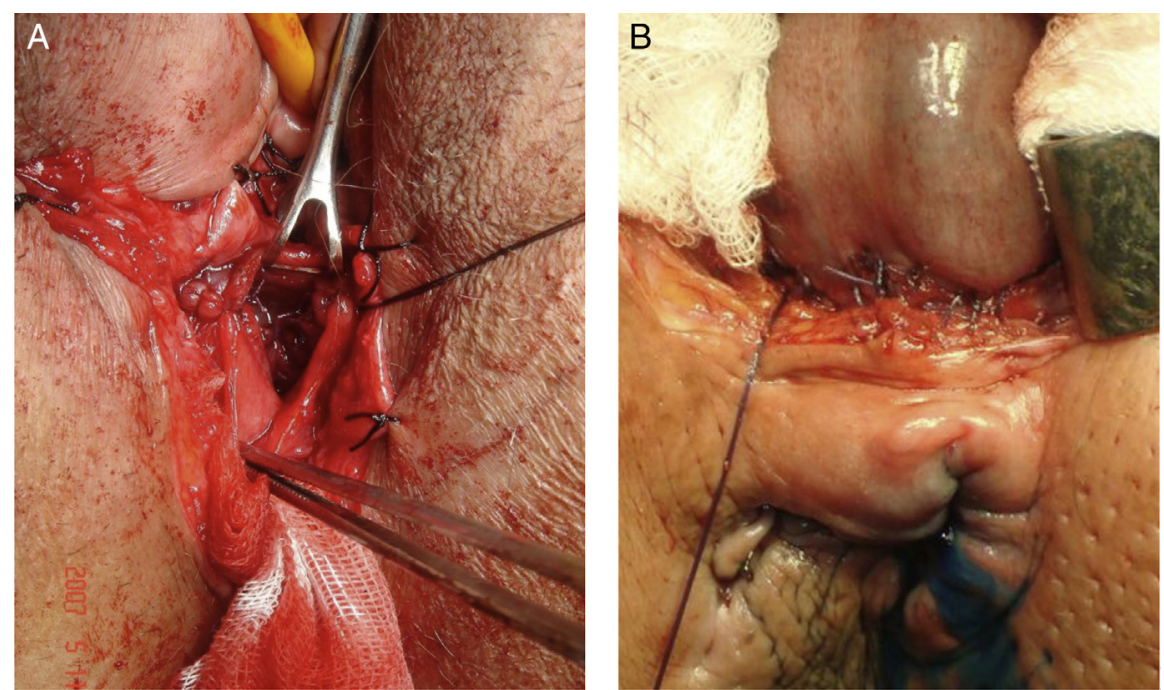

Fig. 3 - A, a full-thickness colo-anal anastomosis by using transvaginal anterior perineal approach in a female patient; B, a full-thickness colo-anal anastomosis by using anterior transperineal approach in a male patient. 


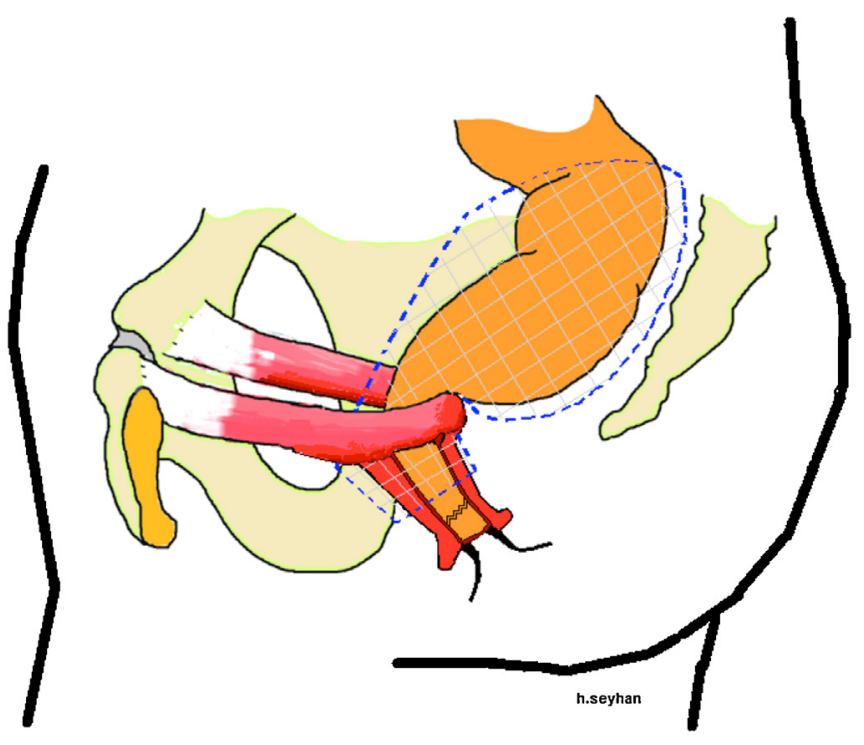

Fig. 4 - Illustration of the resection borders of the combined abdominal and perineal rectal resection operation.

\section{Results}

The original search yielded 26 articles. 10 articles including the case report and series related with combined abdominal and perineal approaches were retrieved and reviewed. ${ }^{7-16}$ The results of the combined abdominal and perineal approaches performed for lower rectal cancer are summarized in Table 1. A total of 83 cases with lower rectal cancer had been operated by using the combined abdominal and perineal approaches. When the cases are examined by gender, the males were found to be around $60 \%$, and the females were found as around $40 \%$. While the anterior perineal approach had been used in 64 cases, the posterior perineal approach had been used in 19 cases.

One mortality was reported in a total of 83 cases. No circular margine positivity was reported. Average Wexner's continence score was reported between 5 and 5.5; and the average number of daily defecation was noted as between 3 and 4 times. Postoperative anal sphincteric pressure measurements revealed slight decreases in the maximum anal squeezing pressure values and no significant differences in the resting anal pressure values. Postoperative perineal infection and persistent perineal fistulas are the most common complications in the patients operated by combined abdominal and perineal approaches for lower rectal cancer. Average persistent perineal fistula development was reported in $9.6 \%$ of the cases. While the persistent perineal fistula development was reported around $12.5 \%$ in the cases operated by anterior perineal approaches, and no perineal fistula development was reported in the patients operated by posterior perineal approaches, which is an interesting result.

\begin{tabular}{|c|c|c|c|c|}
\hline Authors & $\begin{array}{l}\text { Surgical } \\
\text { technique }\end{array}$ & $\begin{array}{l}\text { Number of } \\
\text { the patients }\end{array}$ & Continence & Morbidity and mortality \\
\hline Pena et al. (2003) & CAPPA & 6 & $\begin{array}{l}\text { Continence to solid and liquid } \\
\text { stool }\end{array}$ & $\begin{array}{l}\text { No death } \\
\text { No complications }\end{array}$ \\
\hline Williams et al. (2008) & CAAPA & 5 & The average Wexner score 5 & $\begin{array}{l}\text { No death } \\
\text { Persistent perineal fistula in } 3 \text { patients }\end{array}$ \\
\hline Agrawal et al. (2009) & CAAPA & 7 & $\begin{array}{l}\text { Continence to solid and liquid } \\
\text { stool }\end{array}$ & $\begin{array}{l}\text { No death } \\
\text { Anastomotic stricture in } 2 \text { patients } \\
\text { Rectovaginal fistula in } 1 \text { patient }\end{array}$ \\
\hline $\begin{array}{l}\text { Marquardt et al. } \\
\quad(2012)\end{array}$ & CAAPA & 1 & $\begin{array}{l}\text { No comments on postoperative } \\
\text { period }\end{array}$ & No comments on postoperative period \\
\hline Qui et al. (2012) & CAAPA & 17 & The average Wexner score 5.5 & $\begin{array}{l}\text { No death } \\
\text { Perineal wound infection in } 4 \text { patients }\end{array}$ \\
\hline Di Paulo et al. (2013) & CAAPA & 5 & $\begin{array}{l}\text { Continence to solid and liquid } \\
\text { stool }\end{array}$ & $\begin{array}{l}\text { No death } \\
\text { Perineal wound infection in } 3 \text { patients } \\
\text { Persistent perineal fistula in } 2 \text { patients }\end{array}$ \\
\hline Azizi et al. (2014) & CAAPA & 15 & The average Wexner score 5.5 & $\begin{array}{l}\text { No death } \\
\text { No complications }\end{array}$ \\
\hline Hao et al. (2014) & CAPPA & 13 & The average Wexner score 4 & $\begin{array}{l}\text { No death } \\
\text { Perineal wound infection in } 3 \text { patients } \\
\text { Persistent sacral pain in } 2 \text { patients }\end{array}$ \\
\hline Yücesoy et al. (2014) & CAAPA & 7 & $\begin{array}{l}\text { Continence to solid and liquid } \\
\text { stool }\end{array}$ & $\begin{array}{l}\text { One death } \\
\text { Anastomotic stricture in } 2 \text { patients } \\
\text { Persitent perineal fistula in } 1 \text { patient }\end{array}$ \\
\hline $\begin{array}{l}\text { Abou-Zeid et al. } \\
\text { (2015) }\end{array}$ & CAAPA & 7 & $\begin{array}{l}\text { Continence to solid and liquid } \\
\text { stool in } 4 \text { patients, } \\
\text { No continence in } 3 \text { patients }\end{array}$ & $\begin{array}{l}\text { No death } \\
\text { Persistent perineal fistula in } 1 \text { patient }\end{array}$ \\
\hline
\end{tabular}




\section{Discussion}

There is a common truth behind of the all conceptually similar scientific studies. Anatomical and surgical definitions of a surgical process must be made to evaluate its results. All of the combined abdominal and anterior perineal (transperineal, transvaginal) approaches have been based on similar anatomical and surgical features. Also, posterior perineal approaches have been based on anatomical and surgical features similar to the anterior perineal approaches. ${ }^{14,16}$ The combined abdominal and perineal approaches can be defined as sphincter-saving surgical techniques in which the extrasphincteric dissection and proximal segmental sphincteric excision procedures are performed. ${ }^{16,17}$ The lower rectal cancer surgery is still controversial with high locoregional recurrence and permanent colostomy rates. Combined abdominal and perineal rectal resection techniques have different anatomical and surgical features when compared with intersphincteric dissection technique which is the most commonly used sphincter-saving surgical technique for lower rectal cancer. While evaluating the clinical outcomes of the combined approaches, it should be kept in mind that the combined abdominal and perineal approaches are performed on the basis of the extrasphincteric dissection and proximal segmental sphincteric excision procedures, unlike the intersphincteric dissection technique. The most important surgical point of the combined abdominal and perineal rectal resection techniques is the implementation of the sphincter-saving extrasphincteric rectal dissection procedure. Anal continence and local tumoral staging are prominent as the main evaluation criterias of the combined abdominal and perineal approaches, when looked from that point of view. Oncologic safety and anal continence are the most important expectations in the lower rectal cancer patients operated with sphincter-saving surgical techniques. It has been proven that the cylindrical abdominoperineal excision technique has the oncologic superiority compared with intersphincteric dissection technique in the lower rectal cancer surgical treatment. The cylindrical abdominoperineal excision is based on to the extrasphincteric rectal dissection technique. It was shown that extrasphincteric rectal dissection in the patients operated with the cylindrical abdominoperineal rectal amputation technique for lower rectal cancer have direct impacts on local staging and local staging factors like circular resection margine positivity and tumoral perforation. ${ }^{18,19}$

The Circumferential Resection Margine (CRM) term is used for tumor cell existence at the radial borders of the resected specimen. The lower rectal carcinomas have the higher CRM involvement compared with tumors localized at the other parts of the rectum. Anatomically, the lower rectum is situated into the funnel-shaped pelvic floor. A lower rectal cancer that reaches to the radial border may be in direct contact with external sphincteric musculature in ischioanal fossa or may be surrounded by the narrow mesorectal tissue in the sublevator pelvic cavity depending on its localization level. After arising in the mucosa, rectal cancer makes local invasion in the bowel wall chiefly at the radial direction towards to serosa. The tumoral cell existence at the circumferential border in the histopathologic examination is important as the tumoral cell existence at the proximal and distal resection boundaries, after the surgical excision is performed. It has been reported that the circumferential margine involvements by the tumoral cells is found between 10 and $30 \%$ in the lower rectal cancer cases operated with the intersphincteric dissection technique depending on its local invasion in the bowel wall. ${ }^{20-22}$ CRM involvement has a great importance as a predictive factor for the locoregional recurrence and distant metastasis. CRM positivity can be accepted as the remaining tumor cell existence at the perirectal tissues after the rectal excision. A direct correlation between the locoregional recurrence and CRM positivity ratios has been observed. CRM positivity can be detected in the patients who have $\mathrm{T}_{2}$ or $\mathrm{T}_{3}$ local rectal cancer operated by using the inappropriate intersphincteric dissection technique. If a locally $\mathrm{T}_{2}$ or $\mathrm{T}_{3}$ rectal tumor is found to be as positive circumferential resection border in the histopathologic examination, it should be considered as $\mathrm{T}_{4}$ rectal tumor, which means that the tumor cells are revealed out from the embryonic fascial package. One of the main reason of the higher locoregional recurrence and distant recurrence ratios in the patients who have CRM positive lower rectal cancer can be explained by the revealed tumor cells at the operation area after the surgical resection. Significant decreases in the CRM positivity and tumor perforation ratios have been shown in the patients operated by the extrasphincteric dissection technique for lower rectal cancer. ${ }^{18,19}$ CRM positivitiy has not been reported the in the patients, who were included into this review, who were operated by the combined and perineal approaches. These results were found to be similar to the results of the cylindrical abdominoperineal amputation technique performed in the extrasphincteric plane for the lower rectal cancer surgical treatment. We think that the main reason of these similarities is the sphincter-saving extrasphincteric dissection technique used in the patients operated by combined approaches.

Another important surgical point in the patients operated by the combined abdominal and perineal approaches is to perform the proximal segmental sphincteric excision. The proximal segmental sphincteric excision may cause anxiety concerning the possible continence problems in the postoperative period of the patients. When the case series related with the combined approaches are carefully examined, the patients were found to have enough continence to solid and liquid stool postoperatively. In fact, in the most of the cases operated by combined abdominal and perineal rectal excision techniques, the internal anal sphincteric muscle is protected. Williams showed that the internal anal sphincters were protected in all his patients by means of the endoanal sonography. ${ }^{7}$ Williams, Azizi and Qui showed separately in their postoperative anal sphincteric pressure measurement studies that the patients had the slight decreases in the maximum anal squeezing pressures and had no differences in the resting anal pressure values. ${ }^{7,9,12}$

Although the proximal anal sphincteric segment excision has been applied in patients operated with combined abdominal and perineal approaches, the distal anal sphincteric segment has been found to be sufficient to provide anal continence. Although the combined abdominal and posterior 
perineal approaches had been performed in 6 lower rectal cancer patients without proper oncologic rules by Pena, it is very important that Pena stated that the combined operations, which were carried on the transsphincteric plane along with the proximal sphincteric excision, were completed without complications.

Although permanent fistula rates have been decreased to around $5 \%$ with prolonged suction and subsequent surgical and medical attempts, the persistent fistula development is a bothersome condition both for the patient and for the surgeon in requiring extra effort and time for its treatment, and sometimes it could be the reason of the permanent ileostomy or colostomy. When the perineal sepsis and wound detachments seen in about $30 \%$ of the patients operated with abdominoperineal rectal amputation technique for lower rectal cancer are taken into account; the persistent perineal fistula development in the patients operated by the combined abdominal and perineal approaches is not a big surprise. Interestingly, the persistent perineal fistula development has not been reported in the patients operated by the posterior perineal approaches. This condition can be explained by the predisposition to mixed infections of the anterior perineal region.

Although the combined abdomino-transperineal and abdomino-transanal approaches ${ }^{23,24}$ can be perceived as similar surgical procedures, each of them is based on different surgical and anatomical features. While the combined abdomino-transperineal approaches are performed in the extrasphincteric plane, the combined abdomino-transanal approaches are performed in the intersphincteric plane.

\section{Conclusion}

Intersphincteric dissection technique is the most common used sphincter-saving surgical procedure for the lower rectal cancer surgical treatment. Recently, the combined abdominal and perineal (anterior or posterior) approaches have received a rising interest as a different kind of sphincter-saving surgical procedure in the lower rectal cancer surgery.

The combined abdominal and perineal approaches are based on different anatomical and surgical bases when compared with intersphincteric dissection technique. Although the combined abdomino-transperineal approaches seems to have higher complication ratios compared to the intersphincteric dissection technique, it should be remembered that the combined abdomino-transperineal approaches are performed in the extrasphincteric plane and have local oncologic advantages of the extrasphincteric dissection. More detailed results about the combined abdominal and rectal resection techniques may be revealed with larger series. The combined abdominal and perineal approaches must be considered as an alternative sphincter-saving surgical method especially in the surgical treatment of the lower rectal cancer.

\section{Conflicts of interest}

The author declares no conflicts of interest.

\section{REFEREN CES}

1. Heald RJ, Husband EM, Ryall RD. The mesorectum in rectal cancer surgery: the clue to pelvic recurrence? Br J Surg. 1982;69:613-6.

2. Castro AF. Vaginal approach in resection of low-lying malignant lesions. Tex Med. 1974;69:65-9.

3. Mason AY. Trans-sphincteric exposure of the rectum. Ann R Coll Surg Eng. 1972;51:320-33.

4. Localio SA, Baron B. Abdomino-transsacral resection and anastomosis for mid-rectal cancer. Ann Surg. 1973;178:540-6.

5. Parks AG. Transanal technique in low rectal anastomosis. Proc R Soc Med. 1972;65:975-6.

6. Schiessel R, Karner-Hanusch J, Herbst F, Teleky B, Wunderlich M. Intersphincteric resection for low rectal tumours. Br J Surg. 1994;81:1376-8.

7. Williams NS, Murphy J, Knowles CH. Anterior perineal plan for ultra-low anterior resection of the rectum (the APPEAR technique): a prospective clinical trial of a new procedure. Ann Surg. 2008;247:750-8.

8. Yücesoy AN. The techniques of sphincter-saving extrasphincteric dissection and proximal segmental sphincteric excision in low rectal cancer surgery. Turk J Surg. 2014;30:39-43.

9. Azizi R, Behboo R, Abdollahi A. Anterior perineal plane technique in low rectal cancer. Ann Colorectal Res. 2014;2:e17014.

10. Di Palo S, De Nardi P, Chiari D, Gazzetta P, Staudacher C. Laparoscopic TME with APPEAR (anterior and perineal plane for ultra-low anterior resection of the rectum) technique for distal rectal cancer. Surg Endosc. 2013;27:3430.

11. Marquardt C, Koppes P, Weimann D, Schiedeck T. Laparoscopic ultralow anterior rectal resection in APPEAR technique for deep rectal cancer. Int J Colorectal Dis. 2012;27:549-52.

12. Qiu HZ, Xiao Y, Lin GL, Wu B, Niu BZ, Zhou JL. Clinical application of anterior perineal plane for ultralow anterior resection of the rectum. Zhonghua Wei Chang Wai Ke Za Zhi. 2012;15:47-50.

13. Agrawal V, Mishra A, Raina VK, Sharma D. Abdominoanterior sagittal approach for sphincter-saving ow anterior resection for carcinoma of the rectum in females: a modified anatomical approach. Tech Coloproctol. 2009;13:145-9.

14. Qu Hao, Du Yan-Fu, Li Min-Zhe, Zhang Yu-Dong, Shen Jian. Laparoscopy-assisted posterior low anterior resection of rectal cancer. BMC Gastroenterol. 2014;14:158.

15. Abou-Zeid AA, El-Ghamrini Y, Youssef T. The combined abdominal and perineal approach for dissection of the lower rectum. Int J Surg. 2015;13:217.

16. Pena A, Hong A. The posterior sagittal trans-sphincteric and trans-rectal approaches. Tech Coloproctol. 2003;7:35-44.

17. Yücesoy AN, Poçan S. Letter to editor on "The combined abdominal and perineal approach for dissection of the rectum. The development of new indications". How can we describe the anatomical and surgical basisof the combined abdominal and perineal approaches in lower rectal cancer surgery? Int J Surg. 2015;19:33-4.

18. Stelzner S, Hellmich G, Schubert C, Puffer E, Haroske G, Witziqmann H. Short-term outcome of extra-levator abdominoperineal excision for rectal cancer. Int J Colorectal Dis. 2011;26:919-25.

19. West NP, Finan PJ, Anderin C, Lindholm J, Holm T, Quirke P. Evidence of the oncologic superiority of cylindrical abdominoperineal excision for low rectal cancer. J Clin Oncol. 2008;26:3517-22.

20. Nagtegaal ID, van de velde CJH, Marijnen CAM, van Krieken JHJM, Quirke P. Low rectal cancer: a call for a change of 
approach in abdominoperineal resection. J Clin Oncol. 2005;23:9257-64.

21. Nagtegaal ID, Quirke P. What is the role for the circumferential margin in the modern treatment of rectal cancer? J Clin Oncol. 2008;26:303-12.

22. Adam IJ, Mohamdee MO, Martin IG, Scott N, Finan PJ, Johnston $D$, et al. Role of circumferential margin involvement in the local recurrence of rectal cancer. Lancet. 1994;10:707-11.
23. Atallah S, Albert M, Larach S. Transanal minimally invasive surgery: a giant leap forward. Surg Endosc. 2010;24:2200-20.

24. Teramoto T, Watanabe M, Kitajima M. Per anum intersphincteric rectal dissection with direct coloanal anastomosis for lower rectal cancer. The ultimate sphincter-preserving operation. Dis Colon Rectum. 1997;40:43-7. 